\title{
THE DRIVING POWER OF LEATHER BELTS.
}

\author{
By Robert Briggs, C. E.
}

In the Journal of The Franklin Institute for May will be found a translation of a paper on leather belts, which paper appeared in a communication to the Industrial Society of Mulhouse, in May, 1835. The following is the basis of the paper:

"The science of applied mechanics gives the formula relating to this subject as follows: Calling

$P$, the resistance to be overcome, $e$, the base of Naperian logarithms,

$f$, the coefficient of friction of leather upon cast iron,

$R$, the radius of the pulley,

$s$, the length of the are of contact.

"The formula is written thus:

$$
\text { Friction }=P\left((e)^{\frac{f S}{R}}-1\right)
$$

It is late to correct an erroneous deduction of forty-four years since, but as the paper is resuscitated with the evident purpose of showing or comparing the applicability of its results to present use, it is yet necessary to show that the whole article was founded on a mistake.

Adopting the formula in its present shape of

$$
\text { Friction }=P\left((e)^{\frac{f s}{R}}-1\right)
$$

It will be found there should be placed for the word "Friction" some letter or character which should express the difference of tension between the tight and the slack side of the belt, that is the effective pull of the belt, and the value for $P$ is that of the tension on the slack side of the belt.

The correct formulæ are :

$$
\begin{array}{ll}
\text { Calling } & T_{1}=\text { tension on tight side of belt, } \\
& T_{2}=\text { " " slack " " " } \\
& P=\text { effective pull on the belt }=T_{1}-T_{2} .
\end{array}
$$


Then the "science of applied mechanics"* gives:

$$
\begin{gathered}
\frac{T_{1}}{T_{2}}=e^{\frac{f S}{R}} \\
P=T_{1}\left(\frac{e^{\frac{f S}{R}}-1}{e^{\frac{f S}{R}}}\right) \\
P=T_{2}\left(\frac{f s}{R}-1\right)
\end{gathered}
$$

The last of these formulæ is evidently that used by Mr. Heilmann. The capability of the belt is manifestly its strength to resist the tension $T_{1}$ on the tight side of the belt, and consequently the figures of comparison of ratio of the effective pull to the tension on the slack side of the belt (which are those given in the paper) possess no practical value whatever.

While calling attention to the mistaken use of formula in this computation, it may be proper to show what would have proceeded from correct use with the data accepted by M. Heilmann ; taking Moran's coefficient of friction and M. Laborde's table of force exerted by pulleys with $180^{\circ}$ contact. When the ratio of effective force $=P$ to the tension on the tight side of a belt $=T_{1}$ for different angles of contact; for 0.122 frictional adhesion of belt to pulley becomes :

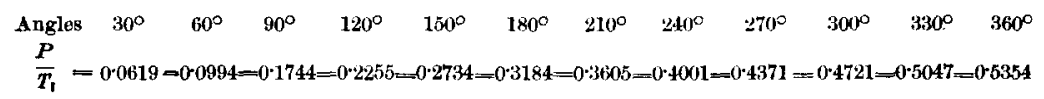

These figures give the multipliers of widths of belts as given in $\mathbf{M}$. Laborde's tables for various angles of contact.

$$
=5 \cdot 344=3 \cdot 203=1 \cdot 826=1 \cdot 431=1 \cdot 165=0=0 \cdot 883=0 \cdot 796=0728-0 \cdot 674=0631=05595
$$

The above figures, however, possess only the merit of accurate computation; not having the least of use, as the coefficient of friction on which they are based is three and a half times too small for conformity with any practice.

It will be noticed that the paper assumes a value for $f$. "'The ratio of friction to pressure for leather upon plane surfaces of cast iron has been taken from the experiments of M. Morin." A simple retrograd-

\footnotetext{
* "Rankine's Applied Mechanics," p. 618; the same will be found in any work on applied mechanics.
} 
ing computation finds from the tables this assumed value to have been 0.122. Direct experiments, which can be repeated by any mechanic at any moment, have shown this ratio to be as large as 0.58 under favorable conditions, and that over 0.40 can be accepted as the hold of the belt in general practice.

In the JournaI (volume CVI), November, 1878, p. 309, the comment upon M. Laborde's paper computes the strain on the belts accepted as a basis by M. Laborde at $19 \cdot 15$ pounds per inch of width. This computation makes no distinction between the strain on the tight side of the belt and the effective strain on the same side accepted by M. Laborde as the measure of imparted force. If the friction of a belt on its. pulley be taken at 0.42 and the angle of contact $180^{\circ}$, then the tension on the tight side of a belt exerting an effective pull of $19 \cdot 15$ pounds is 26.26 pounds and the tension on the slack side will be $7 \cdot 11$ pounds.

It may be well to recapitulate a table which was given some years since in the Journal of the Franklin Instirute.*

\begin{tabular}{|c|c|c|c|c|c|c|c|c|c|c|}
\hline $\begin{array}{l}\text { pulleys, } 0.42 \text {. } \\
\text { Arc of contact, }\end{array}$ & $80^{\circ}$ & $100^{\circ}$ & $110^{\circ}$ & $120^{\circ}$ & $135^{\circ}$ & $150^{\circ}$ & $180^{\circ}$ & $210^{\circ}$ & $240^{\circ}$ & $270^{\circ}$ \\
\hline Strain transmitted (pounds), & $32 \cdot 36$ & $34 \cdot 80$ & $37 \cdot 07$ & $39 \cdot 18$ & $42 \cdot 06$ & $44 \cdot 64$ & $49-01$ & $52 \cdot 53$ & 55.34 & $57 \cdot 58$ \\
\hline Tension, loose side, & $34 \cdot 31$ & $31 \cdot 87$ & $29 \cdot 60$ & $27 \cdot 49$ & $24 \cdot 61$ & $22 \cdot 03$ & $17 \cdot 66$ & $14 \cdot 14$ & $11 \cdot 33$ & $9 \cdot 09$ \\
\hline Total tension on belt, & $100 \cdot 98$ & $98 \cdot 54$ & $96 \cdot 27$ & $94-16$ & $91 \cdot 28$ & $88 \cdot 70$ & $84 \cdot 33$ & $80 \cdot 81$ & $78 \cdot 00$ & $75 \cdot 76$. \\
\hline $\begin{array}{l}\text { Strain between axes of pulleys de- } \\
\text { rived from the belt when at } \\
\text { work, }\end{array}$ & $71 \cdot 40$ & $75 \cdot 94$ & $78 \cdot 85$ & $81 \cdot 54$ & $84 \cdot 32$ & $85 \cdot 68$ & $84: 33$ & $78 \cdot 07$ & 67.55 & $53 \cdot 56$ \\
\hline Tension on each side when at rest, & $50 \cdot 49$ & $49 \cdot 27$ & $48 \cdot 14$ & $47 \cdot 08$ & $45 \cdot 64$ & $44 \div 35$ & $42 \cdot 17$ & $40 * 41$ & $39 \cdot 00$ & $37 \cdot 88$ \\
\hline
\end{tabular}

The last line shows how tight a belt must be made in order to give out its maximum strain of $66 \frac{2}{3}$ pounds per inch of width when at work.

Telegraphic Announcement of Freshets.-The minister of public works is experimenting upon the Lot, in the Department of l'Arveyron, with an electric dpparatus for producing an automatic record of the variations in the level of rivers, so as to signal the occurrence of freshets as soon as they arise, in order to give the inhabitants of the river banks as much time as possible to ward off the danger. The apparatus employed is similar to one that was invented by one of the government engineers who is in the Algerian service. Professor Codazza, Sig. Cabella and Professor Ferrini have also devised indica-. tors for the same purpose.-L'Electricité; Il Politecnico.

\footnotetext{
* January, 1868.
} 